\title{
PEMBICARAAN RINGKAS PUISI-PUISI SUBAGIO SASTROWARDOYO
}

\author{
Zen Hae \\ Bahasa dan Sastra IKIP Universitas Negeri Jakarta \\ zenhae@gmail.com
}

\begin{abstract}
Abstrak
Tulisan ini mencoba membahas kembali segi-segi terpenting puisi Subagio Sastrowardoyo. Pada mulanya ia mencoba mendudukkan Subagio dalam peta sastra Indonesia modern seraya membandingkannya dengan pendahulu dan kawan-kawan penyair segenerasinya. Dalam perbandingan ini tampak perbedaan dan ciri-ciri penting Subagio, terutama lagi sumbangannya pada puisi Indonesia hari ini. Yakni dengan memperkenalkan kembali-puisi esai" (essay poem/essayistic poetry) yang sudah lebih dulu tumbuh dalam khazanah sastra asing. Dalam jenis ini puisi Subagio tampak sebagai upaya berpikir yang tak habis-habisnya, yang lebih menonjolkan yang abstrak ketimbang yang indrawi, yang prosais daripada yang puitis. Sebagai puisi yang prosais puisi-puisi Subagio tampak bukan sekadar penceritaan kembali akan khazanah tertentu, misalnya mitologi perwayangan, tetapi subversi terhadap kisah asalnya. Di bagian lain, puisi Subagio juga menunjukkan wataknya sebagai puisi simbolis yang kuat, di samping mencoba merumuskan kembali puisi di dalam puisi (ars poetica), sebuah cara untuk menyajikan ironi terhadap puisi dan jalan kepenyairan yang dipilihnya.
\end{abstract}

Kata kunci: Subagio, puisi esai, prosais, subversi

\section{Abstract}

This paper attempts to discuss the return of the most important aspects of poetry Subagio Sastrowardoyo. At first he tried to sit Subagio in modern Indonesian literature map by comparing with predecessor and fellow poet of bis generation. In this comparison, its difference and important characteristics are found, especially their contribution to today's Indonesian that is by reintroducing "poetic essays" (essay poem/ essayistic poetry) which had already been growing in the treasures of foreign literature. In Subagio's type, poetry is seen as an attempt to think the endless, which further underline abstract rather than the sensory which is prosaic rather than poetic. As prosaic poem, Subagio seems not merely retelling certain treasures, such as puppetry mythology, but the subversion of the origin story. In other parts, Subagio's poetry also shows his character as a strong symbolic poetry and also trying to reformulate the poems in the poetry (Ars Poetica) as a way to present poetry and irony in his chosen style of writing poems.

Keywords: Subagio, essayistic poetry, prose writer, subversion

\section{Pendahuluan}

Lewat esainya yang berjudul "Orientasi Budaya Chairil Anwar" Subagio Sastrowardoyo telah menyatakan bahwa Chairil Anwar dan penyair-penyair segenerasinya tidak melihat perbedaan Timur dan Barat, karena yang hendak dituju adalah humanisme yang universal. Atau sebagaimana ditegaskan dalam "Surat Kepercayaan Gelanggang (1950), esai pendek Asrul Sani yang kerap dianggap sebagai manifesto Angkatan 45, jika ada "kebudayaan Indonesia" maka itu adalah kebudayaan yang ditetapkan oleh kesatuan berbagai-bagai rangsang suara yang disebabkan suara-suara yang dilontarkan dari segala sudut dunia yang kemudian dilontarkan kembali dalam bentuk suara sendiri" (Sani,1997:3). Orientasi budaya ini tentu saja lebih luwes ketimbang apa yang pernah menjadi sikap generasi Pujangga Baru. Meskipun Sutan Takdir Alisjahbana (STA) sebagai juru bicara angkatan ini menganjurkan bangsa Indonesia yang sedang bangkit ini harus memilih Barat sebagai orientasi budaya, sanggahan yang menganjurkan sebuah sintesis budaya Timur dan Barat, terutama yang dianjurkan Sanoesi Pane, juga tak kalah kerasnya. Di bidang kesusastraan, misalnya, generasi Pujangga Baru mengamalkan soneta sebagai bentuk baru yang diimpor dari Barat (Belanda), tetapi itu sebenarnya hanyalah modernisasi bentuk pantun yang tumbuh dalam khazanah sastra Melayu tradisional. Paradoks 
itu oleh Chairil Anwar dibereskan dengan mereguk seluruhnya sari pati kebudayaan Barat atau dunia. Masalahnya adalah manakah Barat itu? Di bagian lain esainya Subagio menegaskan, Dalam kenyataannya tinjauan hidupnya berpangkal pada dunia budaya Barat dengan lingkaran geografi Eropah Barat dengan Negeri Belanda sebagai pusatnya (Sastrowardoyo,1980:34).

Kritik ini sedikit-banyak berlaku juga untuk Subagio selaku penyair dan kritikus sastra. Meski baru muncul pada paruh kedua dasawarsa 1950-an, orientasi budayanya sebenarnya masih merupakan lanjutan dari orientasi budaya STA dan Chairil Anwar jika bukan gabungan keduanya. Ia adalah laskar terakhir Angkatan 45 yang muncul setelah zaman revolusi. Usianya dua tahun lebih muda dari Chairil Anwar, dan satu tahu lebih tua dari Pramoedya Ananta Toer, tapi ia baru menerbitkan buku puisi pertamanya Simfoni pada 1957, delapan tahun setelah kematian Chairil dan penerbitan novel pertama Pramoedya Perburuan. Di tahun penerbitan buku puisi pertama Subagio itu, terbit pula buku puisi pertama Rendra Ballada Orang-Orang Tercinta. Setahun sebelumnya terbit buku puisi Cari Muatan karya Ajip Rosidi (bersama Sobron Aidit dan S.M. Ardan) dan Pesta, pada 1958 terbit buku puisi pertama Ramadhan K.H. Priangan Si Jelita.

Sebagai laskar terakhir Angkatan 45, Subagiolah yang jelas-jelas meneruskan sembari meluaskan orientasi budaya Chairil Anwar. Jika Subagio mendakwa Chairil hanya berpusat di Negeri Belanda, ia ingin orientasi itu kepada dunia yang lebih luas lagi, negeri (-negeri) asing yang anonim, yang merupakan wilayah pembebasan dan penemuan diri, lawan utama dari negeri yang tiranik dan kampunganpun ke Afrika Selatan, Perjanjian Lama, dan hikayat Seribu Satu Malam. Seperti dalam puisi "Kampung" yang saya kutip lengkap berikut ini:

"Kalau aku pergi ke luar negeri, dik Karena hawa di sini sudah pengap oleh pikiran-pikiran beku.
Hidup di negeri ini seperti di dalam kampung Di mana setiap orang ingin bikin peraturan mengenai lalulintas di gang, jaga malam dan daftar diri di kemantren

Di mana setiap orang ingin bersuara dan berbincang tentang susila, politik dan agama seperti soal-soal yang dikuasai. Di mana setiap orang ingin jadi hakim dan mengeroyok keluarga berdansa, orang asing dan borjuis yang menyendiri.

Di mana tukang jamu disambut dengan hangat, dengan perhatian dan tawanya.

Di mana ocehan di jalan lebih berharga

Dari renungan tenang di kamar.

Di mana curiga lebih mendalam dari cinta dan percaya.

Kalau aku pergi ke luar negeri, dik Karena aku ingin merdeka dan menemukan diri" (Sastrowardoyo, 1995: 12).

Dalam puisi ini "negeri ini" bisa mengacu kepada negara mana pun di dunia ini, tetapi kita tahu ada sejumlah penanda yang khas Indonesia, seperti "tukang jamu", "kemantren", "jaga malam", dan sejumlah kebiasaan buruk lainnya. Dengan begitu kita bisa membangun sebuah penafsiran bahwa si aku menolak sejumlah kebiasaan buruk di negeri ini, Indonesia, yang membuatnya tersiksa sebagai individu. Ia merindukan "luar negeri", sangat mungkin negeri di Eropa atau Amerika Utara, tempat setiap hak asasi individu dijamin oleh hukum sehingga setiap orang "merdeka" dan "menemukan diri" sendiri.

Pendirian ini segera menempatkan Subagio sebagai "lawan" dari hampir semua kawan-kawan segerasinya. Ia penyair yang jelasjelas tidak melayani ambisi kembali ke kampung halaman yang permai sekaligus ringsek, apalagi kembali kepada rakyat banyak ketika Revolusi Agustus 1945 diangggap gagal dan beraksi kembalinya kebudayaan feodal dan imperialis, karena itu mesti diganti dengan kebudayaan yang lebih demokratis, kebudayaan rakyat, sebagaimana dinyatakan oleh kaum Kiri lewat 
Mukadimah Lekra 1950.

Jika Rendra, lewat larik-larik puisi yang ditata dengan tertib dengan permainan rima yang terjaga serupa nyanyian, memperkenalkan balada tentang kematian pahlawan dan pecundang di antara warna-warni alam yang cerah, maka Subagio menyajikan kematian dewa-dewa dan kemustahilan "manusia utama" di dunia seakan hanya keabadian sorga yang bisa menebusnya. Jika Ajip Rosidi dipandang memulai puisi-puisi sosial yang merekam kegetiran hidup di Jakarta sekaligus merindukan kampung yang indah-permai nun di balik kabut, maka Subagio membiarkan kota-kota jahanam itu bernama dan tak bernama, dan kalaupun ada kampung, itulah kampung yang membelenggu manusia dan membuatnya penuh kepalsuan. Jika Ramadhan K.H. dengan puisi yang ringkas pada larik dan ketat pada rima, menampilkan kontras yang tinggi antara keindahan tanah Priangan dan kehancuran akibat perang saudara, maka Subagio dengan penataan larik yang lebih bebas dan hanya sesekali bermain rima, membiarkan latar puisinya tampak hitam, purba, rusak, penuh darah dan dosa.

Latar yang memualkan, situasi yang tanpa harapan, manusia yang terombangambing antara sorga dan dunia, adalah pemandangan umum di dalam puisi-puisi Subagio Sastrowardoyo. Di dalamnya manusia menjadi makhluk yang "salah tempat" setelah terusir dari sorga dan tak bisa kembali lagi ke Taman Firdaus. Sementara fungsinya sebagai wakil Tuhan di bumi telah dibatalkan. Ia bukan hanya mesti menangggung derita dan kesepian sejak kejatuhannya hingga hari akhir, tetapi juga menjelma makhluk haus darah. Dalam puisinya "Dewa Telah Mati" yang menjadi pembuka kumpulan Simfoni, Subagio menegaskan kematian yang lengkap- lengkapnya. Bukan hanya dewa, tetapi juga lelaki jantan dan pertapa, lambang dari manusia yang mau menempuh pelbagai risiko dan manusia yang mencari kesejatian hidup seraya mendamba sorga.

Saya kutip lengkap:

"Tak ada dewa di rawa-rawa ini
Hanya gagak yang mengakak malam hari Dan siang terbang mengitari bangkai pertapa yang terbunuh dekat kuil.

Dewa telah mati di tepi-tepi ini Hanya ular yang mendesir dekat sumber Lalu minum dari mulut

pelacur yang tersenyum dengan bayang sendiri.

Bumi ini perempuan jalang

yang menarik laki-laki jantan dan pertapa ke rawa-rawa mesum ini

dan membunuhnya pagi hari”

(Sastrowardoyo, 1995: 14).

Puisi ini menampakkan setidaknya dua ciri yang menonjol. Pertama, ia menggunakan bentuk puisi empat seuntai (kuatrin) dengan setengah hati. Hanya lariknya yang berjumlah empat, sementara permainan rima akhir dibiarkan sang penyair agak bebas (bandingkan dengan puisinya "Adam dan Firdaus"). Hanya bait pertama yang tampak tertib (aab), dua bait berikutnya dibiarkan lepas. Bunyi "i” di akhir larik, yang tegas maupun yang samar, masih menyarankan suasana yang lirih-perih. Sementara dari hubungan antar-baitnya ia tampak menunjukkan bentuk yang saling berkaitan. Jika bait pertama menegaskan kematian dewa di rawa, kecuali burung gagak yang menandai telah berlangsungnya kematian itu, maka di bait kedua ia kuatkan situasi kematian itu. Pada bait ketiga ditegaskan lagi bahwa perempuan jalang adalah sinonim dari pelacur sekaligus metafora untuk dunia yang membunuh sisa-sisa laskar terakhir, lelaki jantan dan petapa, di pagi hari.

Kedua, suasana maut puisi ini tampak lebih kelam dan menyakitkan ketimbang suasana puisi-puisi Chairil Anwar. Pada sejumlah puisi Chairil (misalnya "1943", "Aku Berkisar Antara Mereka", dan "Malam") dunia yang hancur lebur itu tampak historis, Jakarta di masa revolusi, sisa-sisa derita bom atom dan Perang Dunia Kedua, dan upaya manusia untuk bertahan dari ancaman maut itu terasa revolusioner. Sementara pada puisi Subagio kehancurleburan tampak mitologis dan permanen. Ironis dan 
tanpa harapan sama-sekali.

Kuatnya tema kematian masih kita bisa kita temukan dalam puisi-puisi Subagio yang kemudian, bahkan hingga puisi-puisi terakhirnya sebelum ia berpulang-pokok soal yang juga telah menjadi perhatian Chairil di masa sebelumnya. Tetapi dalam konteks kemunculannya, puisi-puisi Subagio menjadi semacam suara sumbang bagi kerumunan puisi yang berambisi menggerakkan orang banyak dan mengumandangkan optimisme, di tengah karut-marut Indonesia akibat revolusi dan perang saudara. Dengan pesimisme itu sebenarnya ia menempatkan manusia (penyair) pada posisinya yang wajar. Manusia yang menetapkan pilihan sikapnya, di tengah arus pendapat dan kecenderungan umum di masyarakat. Baginya kesusastraan harus bersifat "individuil" Dengan individualitas ini pula ia membawa puisi Indonesia modern kepada tahap yang penting: puisi sebagai renungan filosofis. Ia sendiri pernah menyebut puisinya sebagai semacam-pengentalan pandangan yang filsafat". Dalam suratnya kepada H.B. Jassin, kritikus sastra sekaligus redaktur Mimbar Indonesia yang mengulas Simfoni, Subagio menegaskan seperti ini:

"Bagiku, kesusastraan, lebih lagi puisinya, harus berupa filsafat, yang lahir dari kepenuhan pribadi manusia, filsafat yang berupa pengentalan dan pengendapan pengalaman jasmaniah dan rohaniah. Dan sumber galian pengalaman-pengalaman itu adalah di dalam alam bawahsadar, daerah gelap rahasia itu tetapi kaya akan air hayat, sumber kesadaran yang cerah tentang jagat, manusia dan Tuhan" (dalam Sastrowardoyo, 1971: 50).

Pernyataan semacam ini tentu saja hanya sebatas pernyataan, dan tidak bisa menjadi pedoman yang kokoh untuk menelaah puisipuisi seorang penyair. Tetapi bagian ini cukup menegaskan di mana posisi kepenyairan Subagio Sastrowardoyo. Bagi saya dialah penyair Indonesia modern yang secara sadar menjadikan puisinya sebagai medan perenungan filosofis. (Kelak, kecenderungan ini menguat dalam puisi-puisi Goenawan Mohamad). Kehendak untuk berpikir menggiring puisi-puisi Subagio lebih banyak ke wilayah prosa, dan pelan-pelan meninggalkan watak puisi liris yang tampak dominan dalam panorama puisi Indonesia modern. Apa yang dinyatakan Subagio tampaknya dekat dengan apa yang terjadi pada puisi-puisi Polandia modern. Dalam pengantarnya untuk kumpulan puisi pilihan Wislawa Szymborska, Czeslaw Milosz, penyair Polandia pemenang Hadiah Nobel 1980, menegaskan bahwa puisi-puisi Polandia, termasuk Szymborska di dalamnya, telah menjadi "meditasi eksistensial", dengan meninggalkan puisi murni dan memulai wacana yang selalu tampak prosaic (Szymborska, 2001: 3).

Sebagaimana ditunjukkan Milosz dalam puisi-puisi Szymborska gejala ini salah satunya tampil lewat kecenderungan puisi yang bergerak bolak-balik antara puisi dan esai. Bedanya adalah jika puisi-puisi Szymborska tampak penuh ironi dan humor, maka puisipuisi Subagio menegaskan ironi dan sindiran tetapi tanpa humor sama sekali.

\section{Abstrak, Indrawi, Naratif}

Kehendak untuk menyampaikan pemikiran (filsafat dan lain-lain) pada akhirnya menempatkan puisi-puisi Subagio selalu dalam ketegangan antara "yang abstrak" dan "yang indrawi". Pertentangan itu dalam skala yang sederhana berlangsung antara hasrat menyatakan konsep lewat kata benda abstrak atau kata sifat dan mendedahkan aneka bentuk citraan yang bisa diserap kelima indra kita (terutama penglihatan dan pendengaran), yang karenanya puisi bisa sampai kepada pembaca dalam kesemestaan tubuhnya. Dalam puisipuisi Subagio yang berambisi melancarkan kritik sosial, ketegangan ini tampak memenangkan apa yang abstrak, dan mengesampingkan aneka jenis citraan. Tetapi, dalam konteks ini Subagio sungguh tidak ambil pusing. Sebab baginya kespontanan dan kejujuran jauh lebih penting sebagai esensi puisi, ketimbang menata puisi ke 
dalam larik-larik yang tertib dan menyuarakan kemerduan rima.

Puisi "Daerah Perbatasan" (yang menjadi judul buku puisi kedua Subagio dan terbit pada 1970) memperlihatkan bagaimana hasrat membuat pernyataan dan menggelontorkan pikiran itu menuntut sebanyak mungkin pemakaian kata-kata benda abstrak atau kata sifat (perbatasan, kebimbangan, keputusan, merdeka, kemerdekaan, keselamatan, bahagia, kehormatan, keturunan, kehinaan... tak kurang 22 di bagian I, 30 di bagian II, dan 10 di bagian III). Kata-kata itu pada dirinya sendiri adalah hasil abstraksi mengenai keadaan atau nasib manusia. Dengan bentuknya itu ia telah mengunci konsep tentang sesuai dan tak mungkin diuraikan dalam puisi, kecuali menyerahkannya kepada penafsiran pembaca. Bandingkan, misalnya, dengan puisi "Tentang Kemerdekaan" (1953) karya Toto Sudarto Bachtiar yang mencoba menguraikan atau merinci pengertian kemerdekaan itu dalam tiga larik: "Kemerdekaan ialah tanah air dan laut semua suara/ Jangan takutkepadanya// Kemerdekaan ialah tanah air penyair dan pengembaral Jangan takut kepadanyal/ Kemerdekaan ialah cinta salih yang mesral Bawalah daku kepadanya"(Bachtiar, 1977: 24). Dengan cara begini pembaca mendapatkan bukan hanya batasan tetapi juga uraian dari konsep yang dimaksud. Sementara dalam puisi Subagio pemahaman pembaca akan konsepkonsep itu sudah dianggap final, pembaca dianggap paham akan apa yang dimaksudkan penyair.

Sebab yang memang disasar adalah pemahaman langsung pendengar atau pembaca kepada isi atau pesan puisi itu. Setelah itu adalah sikap si pendengar/pembaca akan pesan yang disampaikan. Saya kutipkan bagian I:

"Kita selalu berada di daerah perbatasan antara menang dan mati.

Tak boleh lagi ada kebimbangan memilih keputusan:

Adakah kita mau merdeka atau dijajah lagi.

Kemerdekaan berarti keselamatan dan bahagia,
Juga kehormatan bagi manusia dan keturunan.

Atau kita menyerah saja kepada kehinaan dan hidup tak berarti.

Lebih baik mati.

Mati lebih mulia

dan kekal daripada seribu tahun terbelenggu dalam penyesalan.

Karena itu kita tetap di pos penjagaan

atau menyusup di lorong-lorong kota pedalaman

dengan pestol di pinggang dan bedil di tangan.

(Sepagi tadi sudah jatuh korban.)

Hidup menuntut pertaruhan, dan kematian hanya

menjamin kita menang.

Tetapkan hati.

Tak boleh lagi ada kebimbangan di tengah kelaliman terus mengancam.

Taruhannya hanya mati" (Sastrowardoyo, 1980: 19).

Dalam bagian ini, sebagaimana bagian II dan III, pemakaian kata-kata abstrak yang ekstensif membuat puisi itu tampak seperti teks pidato. Jika larik-lariknya diketik bersambung terus, tanpa penataan tipografi, ia sungguh tak beda dengan teks pidato seorang komandan perang di depan anggota pasukannya yang cemas dan terancam oleh maut. Dengan penataan tipografi seperti ini memang masih tampak permainan rima akhir. Bahkan jika 12 larik pertama dibagi menjadi masing-masing empat larik, akan tampak permainan rima akhir (abab, aaab, abbb) sebagaimana dalam kuatrin. Namun, hanya permainan rima yang mempertahankan kadar kepuisian dalam puisi ini. Selebihnya adalah rentetan pernyataan pikiran, semburan kata-kata benda abstrak yang ingin menggugah khalayak pendengarnya. Jika ada majas perbandingan itulah yang tampak pada larik 9-11: "Lebih baik mati. Mati lebih mulia/dan kekal daripada seribu tabun/ terbelenggu dalam penyesalan” Majas perbandingan yang diambil Subagio sebagai tampikan atau permainan terhadap pernyataan Chairil Anwar yang amat terkenal, yang diambil dari larik terakhir puisi "Aku" atau "Semangat": "Aku mau bidup seribu tahun lag?".

Sementara puisi "Manusia Pertama di 
Angkasa Luar" memperlihatkan bagaimana kehendak untuk berpikir dan membuat pernyataan itu sebenarnya bisa berlangsung dalam bentuk yang prosais, tetapi di dalamnya masih kita temukan permainan citraan dan penataan bunyi yang cukup tertib dan merdu. Puisi ini terdiri atas dua bait (bait kesatu 38 larik, bait kedua dua larik) yang menghadirkan seorang angkasawan sebagai manusia-ilmuwan yang kesepian di angkasa luar. Di awal si subjeklirik sudah menyatakan posisinya bahwa -aku telah sampaipada tepi/ darimana aku tak mungkin lagi kembali." Sebuah pernyataan yang berimplikasi pada nasibnya di kemudian hari. Suasananya memang monokromatik, tetapi dibangun dengan permainan rima akhir yang cukup sedap: "Aku kini melayang di tengah ruang/Di mana tak terpisab malam dan siang. / Hanya lautan yang hampa dilingkung cemerlang bintang. Bumi tenggelam dan langit makin jauh mengawang." Suasana seperti ini membuat tenang, mengenyangkan, tetapi sebaliknya menyebabkan rindu. Itulah satu jenis perasaan yang tidak intelektualistis dan tidak masuk wilayah sains, jika bukan pernyataan seorang melankolis. Tapi itulah yang membuat ia menjadi manusiawi, rindu kepada segala yang ada di bumi: anak-istrinya, ibunya, barangbarangnya, pergantian cuaca, dan seterusnya. Yang dicita kemudian adalah puisi, "Berilah aku satu kata puisi/daripada seribu rumus ilmu yang penuh janji/yang menyebabkan aku terlontar kini jauh dari bumi/yang kukasib".

Soalnya kemudian, kepada siapa ia meminta puisi? Kepada penyair yang berada di luar puisi itu atau kepada sanak-keluarga di dalam puisi itu tapi bukan penyair? Puisi jenis apa? Bagaimana pula mengirimkannya? Permintaan ini pada akhirnya memang tidak menuntut pemenuhan, hanya untuk menegaskan nasib tragis seorang angkasawan, kaum intelektual, yang mencapai puncak prestasi tertinggi, tetapi merasa kesepian, terpisah dari bumi, sanak-keluarga, puisi. Prestasi yang terusmenerus menjauhkan dirinya dari segala yang ada di bumi tadi: "Aku makin jauh, makin jaub/ Dari bumi yang kukasih. Hari makin sepi/Makin gemurub".// Bunda,/Jangan membiarkan aku sendiri (Sastrowardoyo, 1980: 12).

Yang cukup menarik adalah pernyataan di dua larik terakhir itu: "Bunda,/Jangan membiarkan aku sendiri." Pernyataan ini tentu saja menyadap tenaganya dari kalimat Yesus ketika disalibkan: "Eli, eli, lama sabakbtani." Kalimat ratapan ini juga menegaskan permainan lambang yang selama ini dijalankan Subagio. Bunda di sini bermakna ganda. Ibu sebagai orang tua yang melahirkan anak, juga perlambang dari bumi. Pernyataan yang membenarkan konsep "Ibu bumi" dalam antropologi, sebagaimana ditegaskan Subagio dalam di larik akhir puisi "Parasu Rama: "Bumi adalah ibuku". Apakah itu berarti dengan penerbangan ke angkasa luar ini sang angkasawan ini kembali kepada ayah langit", sebagaimana Muhammad mikraj dan Yesus naik ke langit? Bisa jadi. Jadi, siapa dia selama ini sebenarnya? Manusia biasa atau jelmaan bidadari? Apa sebenarnya fungsi ilmu pengetahuan bagi manusia? Membuat manusia makin sejahtera, beradab, atau bisa juga melayani hasrat manusia sorgawi?

Hasrat untuk menyampaikan pemikiran dalam puisi-puisi Subagio juga bisa berbanding lurus dengan hasrat bercerita. Di samping mengerjakan puisi lirik, Subagio menjalankan puisi naratif_-sebagaimana ia juga menulis sejumlah cerita pendek dan diterbitkan dalam Kejantanan di Sumbing. Jika puisi lirik terasa memadatkan ujaran atau suasana tertentu, dengan pola-pola kuatrin yang nyaris tetap, maka puisi naratif menguraikan atau mencairkannya hingga sampai pada batas tertentu kita mendapatkan semacam bayangan kisah, dengan larik-larik yang kadang dibiarkan bergerak sesuai tuntutan kisah. Itulah yang dilakukan Subagio jika ia berhadapan dengan peristiwa keseharian yang menarik hati, atau fragmen Perjanjian Lama dan mitologi pewayangan yang membuatnya terangsang. Puisi "Manusia Pertama di Angkasa Luar" sedikit banyak mengandung bayangan kisah—sebagaimana puisi "Drama Penyaliban dalam Satu Adegan", "Parasu Rama", "Salju", "Sayap Patah", "Kayal Arjuna", "Hari dan Hara", "Perempuan yang Berumah Dekat Pantai", "Petualang", dan 
"Mata Penyair", sekadar menyebut beberapa judul.

Sudah menjadi rahasia umum, kisah- kisah yang telah menjadi pengetahuan masyarakat tertentu, dari yang zaman kuno hingga masa kini, seperti Adam dan Hawa di Firdaus atau tokoh-tokoh pewayangan, telah merangsang para penulis fiksi dan penyair dari pelbagai negeri dan generasi. Pada puisi naratif yang bersumber dari kisah-kisah ini hampir selalu berlaku rumus "penceritaan kembali" atau "penulisan ulang" yang membuat "kisah" kedua selalu bergerak sebagai alternatif, bahkan subversi terhadap kisah sumbernya. Misalnya puisi- "Kayal" Arjuna berikut ini:
“tanpa sekali
melangkah ke medan Kuru
hanya dibayangkan saja rupa lawannya
di dalam angan-angan
dan ditusuknya dengan
pedang jantung dan perutnya
sehingga keluar darah dan ususnya
dan terang terdengar teriak aduh
dan rubuhnya ke tanah
lelaki itu terbunuh dari jauh
- bagaimana melepaskan dendam birahi?
lihat, ditegangkan pikirannya
di kening terkenang kekasih
mukanya bersimbah peluh
tubuhnya menggeliat dan mengerang
dan dari alat jantannya
mengalir air mani
seperti di dalam mimpi" (Sastrowardoyo, 1975: 88).

Fragmen seperti ini, mungkin, tidak pernah ada dalam wiracarita Mababharata, tetapi Subagio berhasil membangun kisah baru dengan memanfaatkan mitos kesaktian Arjuna sebagai satria penengah Pandawa. Puisi ini tampak subversif, tetapi kreativitas seperti ini selalu dimungkinkan. Dengan ini sebenarnya Subagio ingin menyasar sesuatu yang lain, hal yang pernah dikatakan dalam sebuah esainya "Mengapa Saya Menulis Sajak" (Sastrowardoyo, 1975: 109). Bahwa tokoh-tokoh mitologi seperti itu berbeda dari manusia modern yang banyak pertimbangan moral dan hukum. "Mereka berbicara dan berlaku sesuai dengan desakan yang sejati yang lurus datang dari perasaan serta bayangan batinnya", tulis Subagio.

\section{Lambang dan Permainannya}

Arjuna dalam puisi "Kayal Arjuna" telah menjadi lambang dari kemurnian perasaan dan insting manusia. Sementara Adam adalah lambang dari nasib manusia malang, manusia yang terlempar ke bumi, atau Sita melambangkan keberanian dan pertaruhan perempuan dalam menentukan pilihan hidupnya meski itu harus ditebus oleh kematian. Adapun kulit bawang melambang- kan tubuh manusia yang rusak dan habis diperkuda oleh dunia. Semua ini adalah bagian dari proyek Subagio dalam memainkan lambang dan metafora dalam puisipuisinya. Dalam tataran ini, Subagio sebenarnya berdiri dalam barisan penyair simbolis yang mengeksplorasi beberapa lambang penting dan bersifat sangat pribadi. Dalam puisi-puisi simbolis memang ada pertautan yang erat antara sensibilitas manusia dengan fenomena alam. Penyair menunjukkan perasaannya, atau perasaan manusia yang tengah diceritakannya dalam puisi, dengan mengambil perumpamaan dari alam sekitar. Itulah mengapa puisi-puisi simbolis cenderung mengeksploitasi pelbagai anasir alam (manusia, binatang, tumbuhan) untuk menyatakan apa yang menjadi suara si subjek-lirik. Dalam kasus ini puisi adalah hutan simbol "forest of symbols" (Baudelaire, 1982: 15), tempat manusia (pembaca) bertamasya menyadap aneka makna. Tapi, bagaimanakah itu terjadi? Bagaimana lambang itu muncul dan apa pula kaitannya dengan lambang lainnya? Bagaimana pula ia mempengaruhi struktur puisi?

Pada akhirnya, lambang adalah sebentuk metafora juga, yang dengannya seseorang menyatakan sesuatu dengan cara membandingkannya dengan sesuatu yang lain, sebab pada sesuatu yang lain itu terdapat kesamaan karakter dengan apa yang ingin dikatakan. Dengan membandingkan, sebenarnya, seseorang tengah meluaskan karakter atau mencari ciri-ciri umum yang menonjol dari sesuatu yang dimaksudkan dan 
ditemukan persamaannya dengan apa yang ada pada pihak lain. Perbandingannya bukan lagi manusia dengan manusia, tetapi manusia dengan binatang, tumbuhan, benda mati, atau sebaliknya. Ia juga mencoba membandingkan sesuatu yang abstrak dengan yang indrawi. Jika "cinta yang sederhana" dianggap terlalu abstrak, maka ia perlu dibandingkan dengan sesuatu yang lebih nyata. Misalnya, dengan "kata", tetapi dengan kata yang apa? Seorang penyair seperti Sapardi Djoko Damono menurunkan penjelasannya, - dengan kata yang tak sempat diucapkan kayu kepada api yang menjadikannya abu (Damono,1994:91). Kita bisa menarik kesimpulan, cinta yang sederhana adalah cinta yang tetap rahasia, tak terkatakan, yang kelak melenyapkan "pecinta" demi menghadirkan dan membesarkan si "tercinta". Artinya, ia pasrah sekaligus tulus, tanpa pamrih, tapi juga fatal.

Kesimpulan itu baru bisa didapat setelah pembaca merinci apa saja yang menjadi karakteristik lambang tersebut. Karena itu, dalam menangkap makna sebuah metafora/ lambang amatlah perlu meneliti atau mencermati apa-apa yang menjadi karakteristik si lambang. Memang, ada kemungkinan meleset. Artinya, apa yang dicobajadikan lambang berbeda dengan makna yang dimaksudkan. Menurut kritikus I.A. Richards, selalu ada tegangan antara kata yang menjadi "wahana" (vehicle) dengan makna yang sebenarnya (tenor), antara yang tertulis dan yang tersembunyi di baliknya (Preminger,1993:1268). Sesuatu yang dikatakan akan tampil dengan segala keajaibannya sebelum akhirnya kita menemukan apa yang sebenarnya di baliknya. Di mana ia bersembunyi dan bagaimana rupanya, tugas pembacalah menemukannya.

Puisi Subagio Sastrowardoyo "Dewa Telah Mati" yang telah saya kutip di atas, memainkan lambang dan metafora yang sangat dekat dengan Perjanjian Lama. Yakni, Taman Eden, Eva, dan Ular. "Pelacur" atau "perempuan jalang" adalah lambang dari bumi yang penuh dosa dan ancaman maut (rawa-rawa mesum, ular). Ia pelacur yang pada mulanya menggoda dan menarik -laki-laki jantan" (petualang, pemburu dunia) dan "pertapa" (orang salih, pemburu akhirat), lantar membunuh mereka. Tetapi yang dibunuh bukan hanya manusia, tetapi juga dewa sebagai kekuatan ilahiah, penguasa manusia. Dengan terbunuhnya sang dewa, maka hanya tinggal bumi yang menarik sekaligus kejam ini yang tersisa. Artinya, sebenarnya, tidak ada lagi yang tersisa di bumi. Hanya ada binatang (gagak, ular) yang berkuasa di antara bangkai, sebagaimana tergambar dalam rekonstruksi prasejarah.

Puisi ini dengan caranya sendiri telah membalik mitos penciptaan sekaligus melejitkan ironi. Adam, manusia yang memiliki kekuatan ilahiah itu sebenarnya tidak berdaya di atas bumi yang kejam ini. Ia bukan lagi wakil Tuhan di bumi, tetapi korban dari bumi yang ganas. Jika bumi dipercaya sebagai perempuan, puisi ini juga membongkar mitos yang selama ini dilembagakan bahwa manusia (laki-laki) yang diturunkan dari langit akan menguasai bumi, memperkudanya sesuai keinginannya, seperti terekam dalam puisi "Adam dan Firdaus". Tetapi di sini ia telah kalah, justru di pagi hari, saat yang selama ini dianggap sebagai mulainya hari baru, masa tumbuhnya pelbagai harapan hidup.

Permainan lambang dalam puisi "Dewa Telah Mati" tampak bertingkat dan gerakannya mengikat seluruh struktur puisi. Dalam permainan yang lebih sederhana dan singkat, ia memancarkan makna yang tak kalah luasnya. Seperti dalam puisi "Kayon" berikut ini:

$$
\begin{aligned}
& \text { "pohon purba } \\
& \text { di tengah hutan merah tua- } \\
& \text { tahu akan makna dunia maka diam } \\
& \text { tak bicara" (Sastrowardoyo,1975: 88) }
\end{aligned}
$$

Dengan struktur yang memadat serupa haiku, puisi ini memberikan kepada pembaca tantangan penafsiran yang luas sekali. Kayon, yang biasa dipakai untuk pertunjukkan wayang kulit, adalah lambang yang mujarab untuk menggambarkan kesemestaan pengetahuan tentang alam dan manusia. Ia tidak mewartakan 
hal-hal di dalamnya dengan perincian, tetapi cukup diam saja dan menampilkan dirinya apa adanya. Kali ini, rahasia sungguh tidak membutuhkan kata untuk menyingkapnya. Biarkan mereka yang mencari makna yang melakukannya.

Permainan lambang seperti ini, dalam puisi-puisi Subagio, bisa diperluas hingga kepada yang lain lagi, tetapi kepentingannya nyaris tetap. Bahwa seluruh alam isi alam semesta ini adalah perlambang yang bisa digunakan oleh penyair, sepanjang ia punya keterampilan yang cukup untuk memainkan majas perbandingan dan asosiasi antara makna yang ingin dicapai dengan lambang yang dipakai. Kebutuhan ini hampir mutlak. Sebab tanpa lambang atau metafora, tak akan lahir puisi.

\section{Batas Puisi, Ironi Hidup}

Kita telah mendapatkan banyak sekali puisi tentang puisi (ars poetica). Itulah pernyataan penyair tentang bagaimana puisi ditulis dan rumusan pribadi tentang puisi itu sendiri. Subagio mengerjakan beberapa puisi yang di dalamnya menyinggung apa itu puisi dan bagaimana menciptakannya. Tetapi lebih dari itu ia justru mengukur daya tahan puisi, keunggulan sekaligus kekurangannya, jika ia dibandingkan dengan soal-soal lain di dalam kehidupan manusia. Pada batas inilah watak puisi Subagio sebagai medan ironi muncul sangat meyakinkan. Baginya puisi punya batas dan karena itu ia menjadi wajar dan menyenangkan, dan karena itu pula ia menumbuhkan cinta yang terus-menerus dan menunda seorang penyair untuk bunuh diri. Puisi "Sajak" menyatakannya begini:

"Apakah arti sajak ini

Kalau anak semalam batuk-batuk, bau vicks dan kayuputih melekat di kelambu.

Kalau istri terus mengeluh tentang kurang tidur, tentang gajiku yang tekor buat bayar dokter, bujang dan makan sehari.

Kalau terbayang pantalon sudah sebulan sobek tak terjahit. Apakah arti sajak ini
Kalau saban malam aku lama terbangun: hidup ini makin mengikat dan mengurung. Apakah arti sajak ini:

Piaraan anggrek tricolor di rumah atau pelarian kecut ke hari akhir?

Ah, sajak ini, Mengingatkan aku kepada langit dan mega.

Sajak ini mengingatkan kepada kisah dan keabadian.

Sajak ini melupakan aku kepada pisau dan tali.

Sajak ini melupakan kepada bunuh diri” (Sastrowardoyo,1995: 6).

Jika puisi itu tampak sebagai otokritik untuk puisi, puisi "Mata Penyair" justru menegaskan betapa istimewanya penyair dan alangkah berbahayanya jika salah memahami penyair dan puisi. Jika masyarakat miskin dan kelaparan yang tidak paham puisi, tidak mengerti permainan makna di dalamnya, mencoba merebut kemerdekaan penyair itu, maka akan tampak kepedihan dan kedunguan yang tak bertepi. Apalagi memaknai secara harfiah "Mata Penyair" yang katanya bisa mengubah "butiran pasir yang tercecer dari karung menjadi emas di jalan". "Biji mata penyair" adalah organ tubuh yang biasa saja, tetapi "Mata Penyair" adalah alat yang teramat istimewa untuk melihat apaapa yang tidak bisa dilihat manusia kebanyakan. Maka gerombolan orang miskin yang kelaparan dan gusar mengorek, merebus, dan memakan "biji mata penyair" dan tidak terjadi apa-apa. Tetapi sebaliknya, tanpa "biji mata" sang penyair justru melihat "semua begitu indah. Begitu indahnya." Saya kutipkan dua bait terakhir:

"Tetapi rakyat yang putusasa tidak peduli. Mereka renggut mata penyair dari lubang matanya, dan lewat kedua bola matanya mereka melihat dunia sekelilingnya. Tetapi pasir yang tercecer tidak menjadi emas. Mereka menjadi kecewa dan merebus dan melahap kedua bola mata itu. Dan tidak terjadi apa-apa.

Penyair yang buta itu duduk di jendela dan tertawa menghadap ke kota. Tanpa mata dilihatnya semua 
begitu indahnya. Begitu indahnya!" (Sastrowardoyo, 1995: 133).

Tegangan antara puisi dan penyair atau puisi dan khalayaknya memang bagian yang menjadi perhatian Subagio, bukan hanya dalam puisi-puisinya, tetapi juga dalam sejumlah esainya. Baginya, ada perbedaan mencolok antara penyair bakat alam dengan penyair yang menggunakan intelektualisme dalam bekerja. Sampai pada tahap ini, baru Subagiolah yang sejak awal menegaskan betapa pentingnya intelektualisme dalam puisi. Soal yang bukan hanya ia anjurkan kepada penyair lain, tetapi ia amalkan dalam puisi. puisinya. Dan itu telah menjebak dirinya dalam ketegangan yang tak habis-habisnya antara memadatkan dan menguraikan ungkapan, antara menggunakan abstraksi dengan mengedepankan pengindraan, antara memeluk dengan teguh puisi dan mengesampingkannya. Soal yang hampir tidak menjadi perhatian Chairil Anwar, sosok yang darinya Subagio mengambil ilham dan memantapkan posisinya dalam khazanah sastra Indonesia modern.

\section{Daftar Pustaka}

Alex Preminger dan TVF Brogan, ed., 1993. The New Princeton Encyclopedia of Poetry and Poetics. New Jersey: Princeton University Press.

Anders, Jaroslaw. 2009. Between Fire and Sleep: Essay on Modern Polish Poetry and Prose. New Haven and London: Yale University Press.

Bachtiar, Toto Sudarto. 1977. Suara. Jakarta: Balai Pustaka.

Baudelaire, Charles. 1982. Les Fleurs du Mal, terjemahan Richard Howard. Boston: David R Godin Publisher.

Damono, Sapardi Djoko. 1994. Hujan Bulan Juni. Jakarta: Grasindo.

Mohamad, Goenawan. 2003. Kesusastraan dan Kekuasaaan. Jakarta: Pustaka Firdaus.

Sani, Asrul. 1950. Surat Kepercayaan Gelanggang. Jakarta: Gramedia Pustaka Utama.

Sastrowardoyo, Subagio. 1971. "Catatan tentang
Simphoni" dalam Simphoni Jakarta: Pustaka Jaya. 1975. Keroncong Motinggo. Jakarta: Pustaka Jaya. .1980. Daerah Perbatasan. Jakarta: Balai Pustaka.

1995. Dan Kematian Makin Akrab. Jakarta: Grasindo.

Szymborska, Wislawa. 2001. Miracle Fair: Selected Poems, terjemahan Joanna Trzeciak. New York: WW Norton \& Company. 